\title{
ОСОБЛИВОСТІ ХОЛІНЕРГІЧНОї РЕГУЛЯЦІї СЕРЦЯ ЩУРІВ РІЗНОї СТАТІ ПРИ ПОШКОДЖЕННІ МІОКАРДА ДЕКСАМЕТАЗОНОМ ТА ЗАСТОСУВАННІ L-КАРНІТИНУ ДЛЯ КОРЕКЦІї ДАНОГО СТАНУ
}

\section{ФВ. Є. Пелих, Ю. А. Свередюк}

ДВНЗ «Тернопільський державний медичний університет імені І. Я. Горбачевського МОз України»

РЕЗЮМЕ. Глюкокортикоїди часто використовуються у лікуванні хронічних запальних захворювань, проте їх тривале застосування супроводжується розвитком ускладнень. Одним із таких ускладнень $\epsilon$ пошкодження міокарда, а пошук нових засобів кардіопротекції передбачає вплив на різноманітні ланки патогенезу, в тому числі й на фізіологічні механізми, що забезпечують природну протекцію. Холінергічна ланка регуляції діяльності серця автономною нервовою системою здатна забезпечити такий захист серцю, і пошук речовин, що модулюють активність даної ланки, зумовлює актуальність даного дослідження.

Мета - оцінити інтенсивність брадикардії при введенні в яремну вену ацетилхоліну та електричному подразненні периферійного відрізка блукаючого нерва електричним струмом за умов пошкодження серця дексаметазоном, а також дії L-карнітину у тварин різної статі.

Матеріал і методи. Експерименти виконано на 48 статевозрілих білих безпородних щурах різної статі, яких було поділено на 4 групи. Інтенсивність брадикардії вивчали за допомогою електрокардіографії на комп'ютерному комплексі «КардіоЛаб СЕ» та електричного стимулятора «ЭСЛ-2».

Результати. У тварин різної статі по-різному змінюється реакція серця на подразнення блукаючого нерва залежно від дії досліджуваних лікарських засобів. У самців інтактної групи інтенсивність брадикардії вища в 1,6 раза порівняно із самками. За умов дії на організм тварин L-карнітину досліджуваний показник був вищий у самців у 3,3 раза, ніж у самок. Застосування лише дексаметазону спричинило інтенсивнішу реакцію у самців порівняно із самками на $35 \%$, а комбінації дексаметазону та L-карнітину - на $15 \%$.

Висновки. Дексаметазон (у дозі 350 мкг/кг маси тварини рег оs) подібно діє на холінореактивність синусового вузла серця щурів різної статі - зменшує чутливість холінорецепторів. На фоні дії дексаметазону холінореактивність синусового вузла тварин різної статі при впливі L-карнітину (в дозі 200 мг/кг маси тварини рег оS) змінюється по різному: у самок чутливість холінорецепторів різко знижується при компенсаторному зростанні інтенсивності вивільнення нейромедіатора у пресинаптичну щілину; у самців чутливість холінорецепторів залишається низькою при помірному зменшенні інтенсивності вивільнення ацетилхоліну.

КлючоBI СлоBA: дексаметазон; L-карнітин; пошкодження міокарда; блукаючий нерв; інтенсивність брадикардії; ацетилхолін.

Вступ. Серцево-судинна патологія на сьогодні $\epsilon$ однією з найважливіших проблем медичної науки й охорони здоров'я. Висока захворюваність і смертність, великі трудові втрати, значна інвалідизація визначають її загальнодержавну значущість. Останнім часом зростає кількість як коронарогенних, так і некоронарогенних пошкоджень міокарда, які виникають в результаті стресу, психічного перенапруження, надмірних фізичних навантажень, приймання лікарських засобів стероїдної будови, що на сьогодні стало однією з найпоширеніших і разом з тим до кінця не вирішених проблем клінічної медицини [1].

Глюкокортикоїди успішно застосовуються протягом тривалого часу для лікування широкого кола хронічних запальних захворювань. Проте, незважаючи на загальноприйняту ефективність, тривале застосування даних препаратів може викликати небажані побічні ефекти, зокрема пошкодження міокарда [2], тому виникає питання, чи можна створити умови для запобігання такій негативній дії для безпечного тривалого режиму лікування даними препаратами. Пошук нових за- собів кардіопротекції передбачає вплив на різноманітні ланки патогенезу, в тому числі й на фізіологічні механізми, що забезпечують природну протекцію. Холінергічна ланка регуляції діяльності серця автономною нервовою системою здатна забезпечити такий захист серцю, і пошук речовин, які модулюють активність даної ланки, зумовлює актуальність даного дослідження. Одним із перспективних та ефективних засобів корекції порушень може бути застосування L-карнітину, який, за даними літератури, сприяє оптимізації спряження окиснення вільних жирних кислот і глюкози [3-5]. L-карнітин - речовина 3 групи четвертинних амінів, відіграє важливу роль в енергетичному обміні міокарда: переносить вільні жирні кислоти всередину мітохондрій і тим самим збільшує доступність субстрату для окисного метаболізму в серці [6]. В умовах ішемії L-карнітин запобігає нагромадженню ефірів жирних кислот, що може привести до виникнення фатальних шлуночкових аритмій [2]. При ішемії вміст у міокарді L-карнітину різко знижується, а приймання L-карнітину дозволяє відновити його 
Огляди літератури, оригінальні дослідження, погляд на проблему, ювілеї

необхідний рівень у серцевому м'язі, позитивно вплинути на метаболізм і функцію лівого шлуночка $[7,8]$.

Мета дослідження - встановлення змін холінергічної регуляції діяльності серця, пошкодженого глюкокортикоїдами, та виявлення модулюючого впливу на неї L-карнітину в щурів різної статі.

Матеріал і методи дослідження. Проведено досліди на 48 статевозрілих нелінійних білих щурах, масою 0,17-0,23 кг. Пошкодження під дією глюкокортикоїдів моделювали шляхом застосування дексаметазону в дозі 350 мкг/кг маси тварини per os протягом 15 днів [9]. Корекцію патологічного стану проводили за допомогою препарату L-карнітину («Агвантар», розчин оральний 20 \%, Ерсель Фарма) у дозі 200 мг/кг маси тварини протягом 19 днів [2]. Чутливість холінорецепторів оцінювали за показником інтенсивності брадикардії, яка виникала після введення в яремну вену екзогенного ацетилхоліну хлориду (в дозі 0,05 мг/кг). Про інтенсивність вивільнення нейромедіатора - ендогенного ацетилхоліну - судили, порівнюючи інтенсивність брадикардії на введення екзогенного ацетилхоліну та інтенсивність брадикардії при електричній стимуляції периферійного відрізка правого п. Vagus. Достовірність отриманих відмінностей між результатами (мінімальний рівень значущості $p<0,05)$ оцінювали за допомогою критеріїв Крускала-Уолліса та Ньюмена-Кейлса (програма BioStat, AnalystSoft Inc.).

Результати й обговорення. Інтенсивність брадикардії на введення в яремну вену ацетилхоліну, а отже, й чутливість холінорецепторів на постсинаптичній мембрані достовірно знизились у всіх групах за винятком самок, які отримували лише L-карнітин (табл. 1). У самок, які зазнали впливу дексаметазону, інтенсивність брадикардії була в 1,5 раза, а в самців - у 1,7 раза нижчою від контрольних тварин. Застосування L-карнітину на фоні пошкодження глюкокортикоїдом по-різному вплинуло на тварин різної статі: у самок аналізований показник став нижчим в 1,8 раза, а у самців не відрізнявся достовірно від тварин, які отримували лише дексаметазон.

Таблиця 1. Інтенсивність брадикардії при введенні ацетилхоліну в яремну вену, $(\mathrm{X} \pm \sigma)$

\begin{tabular}{|l|c|c|c|c|}
\hline \multicolumn{1}{|c|}{ Група тварин } & $\begin{array}{c}1 \text { група } \\
\text { Контроль }\end{array}$ & $\begin{array}{c}2 \text { група } \\
\text { L-карнітин }\end{array}$ & $\begin{array}{c}3 \text { група } \\
\text { Дексаметазон }\end{array}$ & $\begin{array}{c}4 \text { група } \\
\text { Дексаметазон +L-карнітин }\end{array}$ \\
\hline Самки & $4,01 \pm 0,24$ & $3,91 \pm 0,36$ & $2,75 \pm 0,23^{*}$ & $1,54 \pm 0,11^{*}$ \\
\hline Самці & $4,47 \pm 0,32 \#$ & $3,04 \pm 0,37 * \#$ & $2,61 \pm 0,17^{*}$ & $2,71 \pm 0,08^{*} \#$ \\
\hline
\end{tabular}

Примітка: * - достовірна різниця порівняно з показниками тварин 1 групи (по горизонталі); \# - достовірна різниця показника тварин різної статі (по вертикалі).

Реакція серця на подразнення блукаючого нерва щурів усіх дослідних груп порівняно 3 контролем (табл. 2) свідчить про однаковий результуючий ефект на ритм серця досліджуваних тварин. Інтенсивність брадикардії у самок, які отримували L-карнітин, знизилась у 2,8 раза, у самців - на 29 \%. Застосування дексаметазону знизило даний показник на 22 \% у самок та $35 \%$ у самців. Використання даних препаратів у комбінації привело до менш інтенсивної реакції серця на 33 \% у самок та в 2,1 раза у самців. Інтенсивність брадикардії на подразнення блукаючого нерва у самок, які отримували лише дексаметазон, не відрізнялась від такого показника у групі, в якій застосовували дексаметазон та L-карнітин. У самців таке ж порівняння досліджуваного показника свідчило про меншу реакцію серця при комбінації лікарських засобів на $27 \%$, порівняно з тваринами, які отримували лише дексаметазон.

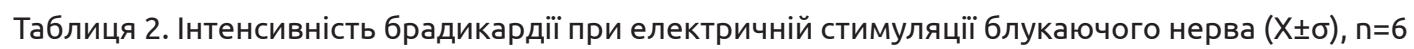

\begin{tabular}{|l|c|c|c|c|}
\hline Група тварин & $\begin{array}{c}1 \text { група } \\
\text { Контроль }\end{array}$ & $\begin{array}{c}2 \text { група } \\
\text { L-карнітин }\end{array}$ & $\begin{array}{c}\text { 3 група } \\
\text { Дексаметазон }\end{array}$ & $\begin{array}{c}4 \text { група } \\
\text { Дексаметазон + L-карнітин }\end{array}$ \\
\hline Самки & $3,92 \pm 0,23$ & $1,39 \pm 0,29^{*}$ & $3,07 \pm 0,17^{*}$ & $2,65 \pm 0,08^{*}$ \\
\hline Самці & $6,34 \pm 0,36 \#$ & $4,52 \pm 0,67^{*} \#$ & $4,15 \pm 0,17^{*} \#$ & $3,03 \pm 0,21^{*} \#$ \\
\hline
\end{tabular}

Примітка: * - достовірна різниця порівняно з показниками тварин 1 групи (по горизонталі); \# - достовірна різниця показника тварин різної статі (по вертикалі).

У тварин різної статі по-різному змінюється реакція серця на подразнення блукаючого нерва залежно від дії досліджуваних лікарських засобів. у самців інтактної групи інтенсивність брадикардії вища в 1,6 раза порівняно із самками. За умов дії на організм тварин L-карнітину досліджуваний показник був вищий у самців у 3,3 раза, ніж у самок. Застосування лише дексаметазону спричинило інтенсивнішу реакцію у самців, порівняно із самками, на 35 \%, а комбінації дексаметазону та L-карнітину - на $15 \%$. 
Огляди літератури, оригінальні дослідження, погляд на проблему, ювілеї

Висновки. Дексаметазон однаково діє на холінергічну регуляцію серця щурів різної статі зменшує чутливість холінорецепторів. На фоні пошкодження міокарда дексаметазоном холінореактивність синусового вузла тварин різної статі при впливі L-карнітину змінюється по-різному: у самок чутливість холінорецепторів різко знижується при компенсаторному зростанні інтенсивності вивільнення нейромедіатора у пресинаптичну щілину. У самців чутливість холінорецепторів залишається низькою при помірному зменшенні інтенсивності вивільнення ацетилхоліну.

\title{
ЛІТЕРАТУРА
}

1. Международный регистр CLARIFY больных со стабильной ишемической болезнью сердца в Украине: особенности, проблемы, перспективы / М. И. Лутай, А. Н. Пархоменко, А. Ф. Лысенко [и др.] // Укр. кардіол. журн. - 2013. - № 3. - С. 13-21.

2. L-carnitine ameliorates gentamicin-induced renal injury in rats / D. Joel, L. Kopple, Hu Ding [et al.] // Nephrol. Dial. Transplant. - 2002. - Vol. 17. - P. 2122-2131.

3. Therapeutic effects of Lcarnitine and propionyl-Lcarni tine on cardiovascular diseases: a review / R. Ferrari, E. Merli, G. Cicchitelli [et al.] // Ann. N Y Acad. Sci. - 2004. Vol. 1033. - P. 79-91.

4. Cardiac metabolism - a promising therapeutic target for heart failure / H. Noordali, B. L. Loudon, M. P. Frenneaux [et al.] // Pharmacol. Ther. - 2017. - Vol. 182. - P. 95-114.

5 . Ringseis $\mathrm{R}$. Role of carnitine in the regulation of glucose homeostasis and insulin sensitivity: evidence from in vivo and in vitro studies with carnitine supplementation

and carnitine deficiency / R. Ringseis, J. Keller, K. Eder // Eur. J. Nutr. - 2011. - Vol. 51 (1). - P. 1-18.

6. Асташкин Е. И. Влияние L-карнитина на оксидативный стресс при сердечно-сосудистых заболеваниях / Е.И.Асташкин, М. Г. Глезер// Медицинский совет.-2016.№ 10. - C. 104-110.

7.L-Carnitine and cardiovascular disease: from basic science to clinical application / Y. Y. Bai, L. Sun, J. H. Liu, R. T. Sun // Cardiology. - 2009. -Vol. 114 (1S). - P. 128.

8. L-carnitine in the secondary prevention of cardiovascular disease: systematic review and meta-analysis / J. J. DiNicolantonio, C. J. Lavie, H. Fares [et al.] // Mayo Clinic Proc. - 2013. - Vol. 88 (6). - P. 5444-5451.

9. Excess of glucocorticoid induces cardiac dysfunction via activating angiotensin II pathway / G. R. Sreerupa, D. Priyanka, M. Debasri [et al.] // Cell Physiol. Biochem. 2009. - Vol. 24. - P. 1-10.

\section{REFERENCES}

1. Lutay, M.I., Parkhomenko, A.N., \& Lysenko, A.F. (2013). Mezhdunarodnyy registr CLARIFY bolnykh so stabilnoy ishemicheskoy boleznyu serdtsa v Ukraine: Osobennosti, problemy, perspektivy. Ukr. Kardiol. Zhurn. - Ukrainian Cardiology Journal, 3, 13-21 [in Russian].

2. Kopple, J.D. (2002). L-carnitine ameliorates gentamicin-induced renal injury in rats. Nephrology Dialysis Transplantation, 17 (12), 2122-2131.

3. Ferrari, R., Merli, E., Cicchitelli, G., Mele, D., Fucili, A., \& Ceconi, C. (2004). Therapeutic Effects of I-Carnitine and Propionyl-l-carnitine on Cardiovascular Diseases: A Review. Annals of the New York Academy of Sciences, 1033 (1), 79-91.

4. Noordali, H., Loudon, B.L., Frenneaux, M.P., \& Madhani, M. (2018). Cardiac metabolism - A promising therapeutic target for heart failure. Pharmacology \& Therapeutics, 182, 95-114.

5. Ringseis, R., Keller, J., \& Eder, K. (2011). Role of carnitine in the regulation of glucose homeostasis and insulin sensitivity: Evidence from in vivo and in vitro studies with

carnitine supplementation and carnitine deficiency. European Journal of Nutrition, 51 (1), 1-18.

6. Astashkyn, E.Y., \& Hlezer, M.H. (2016). L-karnitina na oksydativnyy stress pri serdechnososudystykh zabolevanyyakh [The effect of L-carnitine on oxidative stress in cardiovascular diseases]. Meditsynskyy Sovet - Medical Board, 10, 104-110 [in Russian].

7. Bai, Y.Y., Sun, L., Liu, J. H., \& Sun, R. T. (2009). L-Carnitine and cardiovascular disease: From basic science to clinical application. Cardiology, 114, 1s, 128.

8. Dinicolantonio, J.J., Lavie, C.J., Fares, H., Menezes, A.R., \& Okeefe, J.H. (2013). L-Carnitine in the secondary prevention of cardiovascular disease: systematic review and meta-analysis. Mayo Clinic Proceedings, 88 (6), 544-551.

9. Roy, S.G., De, P., Mukherjee, D., Chander, V., Konar, A., Bandyopadhyay, D., \& Bandyopadhyay, A. (2009). Excess of glucocorticoid induces cardiac dysfunction via activating angiotensin II pathway. Cellular Physiology and Biochemistry, $24(1-2), 1-10$

\section{ОСОБЕННОСТИ ХОЛИНЕРГИЧЕСКОЙ РЕГУЛЯЦИИ СЕРДЦА КРЫС РАЗНОГО ПОЛА ПРИ ПОВРЕЖДЕНИИ МИОКАРДА ДЕКСАМЕТАЗОНОМ И ПРИМЕНЕНИИ L-КАРНИТИНА ДЛЯ КОРРЕКЦИИ ДАННОГО СОСТОЯНИЯ}

\author{
๑В. Е. Пелых, Ю. А. Свередюк
}

ГВУз «Тернопольский государственный медицинский университет имени И. Я. Горбачевського МОз Украины»

РЕЗЮМЕ. Глюкокортикоиды часто используются в лечении хронических воспалительных заболеваний, однако их длительное применение сопровождается развитием осложнений. Одним из таких осложнений является 
Огляди літератури, оригінальні дослідження, погляд на проблему, ювілеї

повреждение миокарда, а поиск новых средств кардиопротекции предполагает воздействие на различные звенья патогенеза, в том числе и на физиологические механизмы, обеспечивающие естественную протекцию. Холинергическое звено регуляции деятельности сердца автономной нервной системой способно обеспечить такую защиту сердцу, и поиск веществ, модулирующих активность этого звена, обусловливает актуальность данного исследования.

Цель - оценить интенсивность брадикардии при введении в яремную вену ацетилхолина и электрическом раздражении периферического отрезка блуждающего нерва электрическим током в условиях повреждения сердца дексаметазоном, а также действия L-карнитина у животных разного пола.

Материал и методы. Эксперименты выполнены на 48 половозрелых белых беспородных крысах разного пола, которыебылиразделенына 4 группы.Интенсивностьбрадикардии изучалиспомощьюэлектрокардиографии на компьютерном комплексе «КардиоЛаб СЕ» и электрического стимулятора «ЭСЛ-2».

Результаты. У животных разного пола по-разному изменяется реакция сердца на раздражение блуждающего нерва в зависимости от действия исследуемых лекарственных средств. У самцов интактной группы интенсивность брадикардии выше в 1,6 раза, по сравнению с самками. В условиях действия на организм животных L-карнитина исследуемый показатель был выше у самцов в 3,3 раза, чем у самок. Применение только дексаметазона вызвало более интенсивную реакцию у самцов, по сравнению с самками, на 35 \%, а комбинация дексаметазона и L-карнитина - на $15 \%$.

Выводы. Дексаметазон (в дозе 350 мкг/кг массы животного рег оs) одинаково действует на холинореактивность синусового узла сердца крыс разного пола - уменьшает чувствительность холинорецепторов. На фоне действия дексаметазона холинореактивность синусового узла животных разного пола при воздействии L-карнитина (в дозе 200 мг/кг массы животного рег оs) изменяется по-разному: у самок чувствительность холинорецепторов резко снижается при компенсаторном росте интенсивности высвобождения нейромедиатора в пресинаптическую щель; у самцов чувствительность холинорецепторов остается низкой при умеренном уменьшении интенсивности высвобождения ацетилхолина.

КЛЮЧЕВЫЕ СЛОВА: дексаметазон; L-карнитин; повреждения миокарда; блуждающий нерв; интенсивность брадикардии; ацетилхолин.

\section{PECULIARITIES OF CHOLINERGIC REGULATION OF THE HEART OF DIFFERENT SEX RATS IN THE DAMAGE OF MYOCARDIUM BY DEXAMETAZON AND USING OF L-CARNITINE FOR CORRECTION}

\section{Horbachevsky Ternopil State Medical University}

@V. Ye. Pelykh, Yu. A. Sverediuk

SUMMARY. Glucocorticoids are often used in the treatment of chronic inflammatory diseases, but their long-term use is accompanied by the development of complications. One of these complications is myocardial damage. Searching of new medications of cardioprotection involves influencing on various links of pathogenesis, including the physiological mechanisms that provide natural protection. The cholinergic link in the regulation of heart activity by the autonomic nervous system is able to provide such protection to the heart and the searching of substances, which modulates the activity of this link determines the topicality of this study.

The aim - to estimate the intensity of bradycardia in acetylcholine injection into the jugular vein and electrical stimulation of the peripheral segment of the vagus nerve by electric current under conditions of heart damage by dexamethasone and action of L-carnitine in animals of different sexes.

Material and Methods. Experiments were performed on 48 adult white outbred rats of different sexes, which were divided into 4 groups. The intensity of bradycardia was studied using electrocardiography on the computer complex CardioLab CE and electrical stimulator ECL-2

Results and Discussion. Dexamethasone (at a dose of $350 \mu \mathrm{g} / \mathrm{kg}$ of animal body weight per os) similarly acts on the cholinergic activity of the sinus node of the heart of rats of different sexes - reduces the sensitivity of the cholinergic receptors. On the background of dexamethasone, the cholinergic activity of the sinus node of animals of different sexes in exposed of L-carnitine ( $200 \mathrm{mg} / \mathrm{kg}$ of animal weight per os) varies differently - in females, the sensitivity of cholinergic receptors decreases sharply with a compensatory increase in the neurotransmitter release rate into the presynaptic cleft. In males, the sensitivity of cholinergic receptors remains low with a moderate decrease in the intensity of acetylcholine release.

KEY WORDS: dexamethasone; L-carnitine; myocardial damage; vagus nerve; bradycardia intensity; acetylcholine.

Отримано 05.02.2019 